\title{
Palavras Introdutórias
}

\section{Jurisdições, Soberanias, Administrações (Primeiras décadas do século XIX)}

\author{
Andréa Slemian* \\ Universidade Federal de São Paulo \\ Guarulhos - São Paulo - Brasil
}

José Reinaldo de Lima Lopes**

Universidade de São Paulo

São Paulo - São Paulo - Brasil

\author{
Alejandro Agüero ${ }^{* * *}$ \\ Universidad Nacional de Córdoba \\ Córdoba - Argentina
}

* Formação: Universidade de São Paulo. Professor Adjunto III no Departamento de História da EFLCH - Universidade Federal de São Paulo.

** Doutor (1991) em direito pela Universidade de São Paulo. Pós-doutorado pela Universidade da Califórnia, São Diego (1995), e livre-docente pela Universidade de São Paulo (2003).

*** Graduado en Derecho por la Universidad Nacional de Córdoba (Argentina), Master Europeo en Historia y Comparación del as Instituciones Jurídicas y Políticas de la Europa Mediterránea por Universidad de Messina (Italia); Doctor en Derecho por Universidad Autónoma de Madrid (España). Cargo: Investigador Independiente CONICET - Prof. Adjunto Historia del DerechoDepartamento: Centro de Investigaciones Jurídicas y Sociales. Facultad: Facultad de Derecho - Universidad Nacional de Córdoba (Arg.).Contacto: aaguero@derecho.unc.edu.ar//aleguero@hotmail.com. 
Se é correto afirmar que as Independências foram uma solução, entre outras, possíveis, para os projetos em curso nas primeiras décadas do século XIX na América Ibérica, é igualmente verdadeiro sustentar que elas geraram um problema central: o da constituição de novas unidades jurídico-políticas de projeção nacional. Como é já sabido, este problema derivou da ausência de uma força política capaz de impor um programa geral nas disputas pela soberania e reconfiguração territorial que se seguiram, tanto na Europa como na América, à crise imperial ibérica desde 1807. Consequentemente, os projetos existentes tinham de afrontar não apenas a definição de seus difusos limites externos, senão também o que llmar Mattos chamou de "expandir-se para dentro" (Matos, 2005). O que exigiu tanto dar novo sentido às unidades políticas anteriores, como vice-reinados, províncias e domínios, quanto reorganizar novos territórios, definindo suas relações entre si com novos centros políticos. Tudo isso imerso na tradição de governo colonial que condicionou o desenvolvimento de novas estratégias e seguiu operando como pano de fundo comum de algumas concepções e práticas institucionais emergentes.

Apesar dos significativos avanços historiográficos sobre esta problemática, entendemos que ainda segue sendo um ponto a explorar o do processo histórico de conformação das unidades interiores com suas soluções políticas e institucionais. Para além de qual tenha sido o "sujeito-espaço político" que predominou em uma ou outra experiência, entendemos que são poucos os estudos comparativos que têm abordado o como, quer dizer, discursos, técnicas, dispositivos institucionais, etc., mediante os quais aqueles "sujeitos-espaço políticos" se consolidaram dentro das novas nações. Esta foi a principal motivação para que realizássemos, em junho de 2016, o Colóquio JURISDIÇÕES, SOBERANIAS, ADMINISTRAÇÕES: A CONFIGURAÇÃO DOS ESPAÇOS politicos na construÇão dos Estados Nacionals na AmÉrica Ibérica, ocorrido na Faculdade de Direito (USP), com financiamento da FAPESP e da CAPES (PAEP), o qual contou com a participação de pesquisadores do Brasil, Argentina, México, Colômbia, Chile, Cuba, Portugal, Espanha, Itália e França. Seu escopo foi discutir a questão no interior das 
novas unidades estatais na América ibérica, com foco na criação dos instrumentos de governo e controle sobre o território e a população durante o século XIX, assim como as tensões suscitadas pela sua implementação; e seu resultado foi muito frutífero, resultando em parcerias e publicações.

Uma delasé o dossiê que aqui se apresenta em que concentramos parte dos textos que discutiram um dos eixos de nossa proposta para oColóquio:osagentesdegoverno(magistrados, oficiais,funcionários, etc.) e seus órgãos tendo como foco os modos deadministração, como seorganizaraminstitucionalmenteosespaçosprovinciais,comoseoperou o processo derecrutamento deagentes doEstado,como sebuscou a ordem pública, entre outros. Os trabalhos aqui reunidos tratam do caso doBrasil, dois delesantes da deflagração do movimento constitucionalista em Portugal, quando já era ali evidente a busca de soluções alternativas à crise da monarquia diante das transformações que se viviam em todo mundo ao redor. Única exceção é um estudo sobre Cuba, o qual se justifica, a despeito da manutenção de seu estatuto colonial, pela semelhança de problemas vividos na ilha diante da herança doselementoscoloniaisnoregimeconstitucionalespanhol;isso sem contar a existência da escravidão, que muito faz pensar sobre o caso brasileiro.

Obviamente, cabe destacar que, no marco de um mesmo conjunto de problemas, estamos diante de uma rica pluralidade de enfoques oferecida pelas autoras. Além da alta qualidade das reflexões presente em todos os trabalhos, uma questão os une no afrontamento da reflexão proposta desde o início: o da qualificação do processo que, em cada um dos temas específicos tratados nos artigos, está longe de ser redutível a uma simples avaliação acerca de suas rupturas ou continuidades. Suas respostas são convergentes à necessidade de conhecer a complexidade deste momento transicional de estabelecimento deregimesconstitucionais, cujassoluções, projetosedisputaspolíticas ocorreriam em meio a um universo contaminado culturalmente por práticas jurídicas consolidadas. 
Neste sentido, alguns textos põem em questão o recurso a dispositivos ou ao modus operandi existentes na organização destes novos espaços nacionais. É o caso do trabalho de Renata Silva Fernandes que analisa as petições apresentadas ao Conselho Geral da Província de Minas Gerais, entre 1828 e 1834, buscando entender suas implicações no processo de criação do poder provincial, mesmo sendo o movimento peticionário prática consolidada no regime anterior. Neste escopo está o caso de Cuba, que Alina Castellanos Rubio afronta por meio da discussão acerca do Tribunal Especial Militar, atuante na primeira metade do XIX como tribunal de intervenção executiva de "excepcionalidade" (para controle da criminalidade, do bandoleirismo, e também crimes políticos), o qual fez parte de um programa consciente de conservação de um equipamento político militar colonial num ambiente de afirmação do regime constitucional espanhol. Numa outra chave, mas tendo em vista a mesma questão, Maria Luiza Oliveira explora os modos de governar dos presidentes das províncias brasileiras por meio das narrativas presentes em suas correspondências, as quais descortinam um quadro de acumulação de saberes e interesses pessoais que buscava lógicas diferentes das que os novos espaços institucionais almejavam construir.

Os revezes desta transição podem serfrequentementevislumbrados no discurso da necessidade de reformas, cuja enunciação, mesmo quando não efetivadas, costuma ser um dado mais que significativo; sobretudoàs vésperasdomovimentoconstitucional nomundoportuguês, em que sefazia necessário estar atento às possibilidades abertas em outras experiências coevas. Este é o caso visível do trabalho de Adriana Barreto de Souza ao analisar a Junta do Código Penal Militar e de Melhoramento das Coudelarias do Reino, instituída pelo príncipe regente D. João em 1802 com o intuito de modernização, em meio a um conjunto de reflexões sobre o foro militar e seu papel na estruturação das suas instituições, em especial do Exército. Tratando especialmentedosimpassesquesecolocaramnoestabelecimentodenovassoluções estão os trabalhos de Adriana Pereira Campos e Cláudia Maria das Graças Chaves. O primeiro, tendo como tema os juízes de paz no 
Brasil, explora os diversos sentidos conferidos àquela magistratura ao longo do período de sua"experimentação", que vai desde sua criação em 1827 até a acomodação de suas funções em 1841, descortinando as contradições presentes na sua concepção e implantação. $O$ segundo, concentra-se na discussão das Juntas da Real Fazenda que, como formas tradicionais e jurisdicionais de administração fazendária, tornaram-se a base dos novos poderes políticos e econômicos regionais quando da criação das Juntas Provisórias de Governo, organizadas desde as Cortes de Lisboa.

A complexidade das soluções experimentadas neste período talvez possa ser mimetizada pela ordem de problemas levantadas no texto de Roberta Stumpf. Ao analisar as modalidades de recrutamento dos oficiais americanos durante o governo joanino, chega à conclusão que a ocorrência de mudanças, por um lado, indicava o reforço do sistema de remuneração de serviços (a economia das mercês), essencial à consolidação do papel do monarca como promotor da justiça distributiva, mas, por outro, anunciava uma tendência de aceitação dos princípios meritocráticos, mesmo que no âmbito de uma monarquia tradicional. Nem apenas o caminho do patrimonialismo, nem somente o da burocracia, servem para sintetizar algo cuja graça está na sua própria história, ou seja, em descortinar como os protagonistas agiram e inventaram, com os instrumentos disponíveis, uma Era que foi vivida como de transformações. Oxalá este conjunto proporcione a seus leitores semelhantes vôos.

MATTOS, Ilmar Rohloff de."Construtores e herdeiros: a trama dos interesses na construção da unidade política". Almanack Braziliense, 1 (2005), pp. 8-26. 